\title{
Pengetahuan, Sikap, dan Tindakan Petani Upsus dalam Mengendalikan Hama dan Penyakit Tanaman Padi
}

\section{(Knowledge, Attitude, and Action of Upsus Farmers in Controling Pest and Disease of Rice Plant)}

\author{
Kurniawan Effendi*, Abdul Munif², I Wayan Winasa ${ }^{3}$
}

(Diterima September 2019/Disetujui Juni 2020)

\begin{abstract}
ABSTRAK
Program Upaya Khusus (Upsus) adalah program pemerintah Indonesia untuk meningkatkan produksi dan produktivitas tanaman padi sawah guna mendukung terwujudnya percepatan swasembada pangan. Sasaran program Upsus adalah peningkatan indeks pertanaman padi sebesar 0,5 dan produktivitas padi sebesar 0,3 ton/ha/GKP. Peningkatan indeks pertanaman dicapai melalui perluasan tambah tanam yang dilakukan, namun peningkatan produktivitas belum tercapai secara optimal karena serangan hama dan penyakit. Penelitian ini bertujuan untuk mengetahui pengetahuan, sikap, dan tindakan petani pelaku Upsus dalam mengendalikan hama dan penyakit dan teknik budi daya padi sawah serta implementasi Upsus di Kabupaten Karawang. Penelitian dilakukan dengan menyebarkan kuesioner kepada 60 orang petani di Kecamatan Tempuran dan Tirtajaya, Kabupaten Karawang. Responden dipilih secara purposive sampling dengan pertimbangan bahwa responden adalah kelompok tani aktif, memiliki pengalaman bertani minimal 5 tahun, dan telah mengikuti Upsus minimal 1 tahun. Sebagian besar responden berada pada kisaran umur 41-60 tahun, pendidikan terakhir sekolah dasar, dan memiliki pengalaman bertani selama 5-10 tahun. Hama dan penyakit adalah masalah terbesar yang dihadapi oleh petani. Petani pelaku Upsus menggunakan varietas Ciherang dan Inpari 32 dan aplikasi pestisida dilakukan secara terjadwal. Sebagian besar petani kurang mampu membedakan antara hama dan penyakit. Pengendalian hama dan penyakit yang dominan dilakukan adalah melalui penggunaan pestisida kimia.
\end{abstract}

Kata kunci: hama, penyakit, pestisida, Upsus

\section{ABSTRACT}

The Special Efforts Program (Upsus) is an Indonesian government program to increase production/productivity of lowland rice to support the realization of food self-sufficiency. The Upsus targets are to increase the planting index by 0.5 and productivity by 0.3 tons/ha/GKP. The increase in planting index is achieved by the expansion of added planting, but the increase in productivity has not been reached optimally due to pest and disease attacks. The objective of this research was to determine the knowledge, attitudes, and actions of Upsus farmers in controlling pests and diseases, rice cultivation techniques, and implementation of Upsus in Karawang District. The research was conducted by distributing questionnaires to 60 farmers in Tempuran and Tirtajaya Sub-District at Karawang District. The respondents were selected by purposive sampling with the consideration of respondent being an active farmer, having at least 5 years of farming experience, and has ben a member of Upsus for at least 1 year. Most respondents have age in the range of 41-60 years, the highest education of elementary school, and have farming experience for 5-10 years. Pests and diseases are the biggest problems faced by the farmers. Upsus farmers used Ciherang and Inpari 32 varieties and the applications of pesticides were conducted according to the schedule. Most of the farmers could not distinguish between pests and diseases. The dominant pest and disease control carried out was the use of chemical pesticides.

Keywords: diseases, pesticides, pests, Upsus

\section{PENDAHULUAN}

Swasembada pangan dapat dicapai melalui upaya peningkatan produksi dan produktivitas tanaman pangan. Program Upsus (upaya khusus) adalah prog-

1 Sekolah Pascasarjana, Fakultas Pertanian, Institut Pertanian Bogor, Kampus IPB Darmaga, Bogor 16680

2 Departemen Proteksi Tanaman, Fakultas Pertanian, Institut Pertanian Bogor, Kampus IPB Darmaga, Bogor 16680

* Penulis Korespondensi:

Email: andieffendi212@gmail.com ram pemerintah Indonesia yang bertujuan untuk meningkatkan produksi dan produktivitas padi sawah guna mewujudkan pencapaian percepatan swasembada pangan. Sasaran Upsus adalah peningkatan indeks pertanaman sebesar 0,5 dan peningkatan produktivitas sebesar 0,3 ton/ha/GKP (Permentan No 3 Tahun 2015). Produktivitas padi sawah pada tahun 2015 adalah sebesar 55,08 kuintal/ha, pada tahun 2016 sebesar 53,97 kuintal/ha, dan pada tahun 2017 sebesar 53,19 kuintal/ha (Kementan 2017). Penurunan produktivitas menunjukkan bahwa sasaran Upsus belum tercapai secara optimal. 
Penurunan produktivitas padi sawah disebabkan oleh serangan hama dan penyakit. Upaya pengendalian dominan yang dilakukan oleh petani adalah penggunaan pestisida kimia. Pengendalian hama dan penyakit yang dianjurkan Upsus mengacu pada prinsip/strategi Pengendalian Hama Terpadu (PHT), di mana pestisida kimia digunakan sebagai alternatif terakhir jika serangan hama dan penyakit telah melebihi ambang ekonomi (Dirjen Tanaman Pangan 2015). Upaya pengendalian yang dilakukan petani pada saat ini sangat jauh dari konsep PHT.

Penerapan PHT pada pelaksanaan Upsus belum dilakukan secara maksimal. Penilaian tingkat keberhasilan PHT dapat diukur berdasarkan tingkat pengetahuan petani mengenai konsep dasar PHT, seperti musuh alami, ekologi/biologi hama, dan komponen pengendalian (Muhammad 1996). Komponen pengendalian $\mathrm{PHT}$ terdiri atas pengendalian kultur teknis, pengendalian hayati, pengendalian kimiawi, pengendalian dengan varietas tahan, pengendalian fisik, pengendalian mekanis, dan pengendalian melalui peraturan karantina (Untung 2006). Penilaian keberhasilan PHT pada program SLPHT sudah banyak dilakukan. Petani SLPHT umumnya sudah mengetahui tentang konsep PHT. Karakteristik petani seperti umur, tingkat pendidikan, dan lama bertani tidak memiliki korelasi yang signifikan dengan tindakan petani dalam menggunakan pestisida. Faktor yang memengaruhi tindakan petani dalam menggunakan pestisida adalah faktor kebiasaan, kemudahan penggunaan, dan tingkat efektivitas pestisida (Hidayat et al. 2010). Penilaian konsep PHT pada program Upsus belum banyak dilakukan. Mengingat upaya pengendalian hama dan penyakit pada program Upsus mengacu pada strategi dan konsep PHT, penilaian konsep PHT pada program Upsus perlu dilakukan.

Kabupaten Karawang dipilih sebagai lokasi penelitian karena merupakan salah satu daerah sentra padi di Jawa Barat dan salah satu daerah pelaksana program Upsus terbesar di Jawa Barat. Tujuan pelaksanaan penelitian ini adalah untuk mengevaluasi pengetahuan, sikap, dan tindakan petani pelaku Upsus dalam mengendalikan hama dan penyakit dan melakukan usaha budi daya padi sawah serta implementasi tahapan program Upsus di tingkat petani.

\section{METODE PENELITIAN}

Penelitian dilaksanakan di Kecamatan Tempuran dan Tirtajaya, Kabupaten Karawang selama 5 bulan (Desember 2018-April 2019). Lokasi kecamatan dipilih berdasarkan luas tanam padi sawah per kecamatan. Kecamatan Tempuran dan Tirtajaya memiliki luas tanam di atas 5.000 ha atau lebih luas dari kecamatan lainnya. Pada Kecamatan Tempuran diambil Desa Lemah Duhur, Lemah Karya, dan Lemah Subur, sedangkan pada Kecamatan Tirtajaya diambil Desa Gempol Karya, Medan Karya, dan Sabajaya. Lokasi desa dipilih secara acak serta berdasarkan pada waktu pelaksanaan kegiatan budi daya tanaman padi sawah. Dari setiap desa terpilih diambil 10 orang petani (30 orang responden/kecamatan). Total jumlah responden yang diwawancarai sebanyak 60 orang. Kegiatan wawancara yang dilakukan terdiri atas pemberian kuesioner dan wawancara mendalam. Wawancara mendalam bertujuan untuk mengetahui permasalahan responden pada saat melaksanakan kegiatan budi daya padi sawah.

Penentuan responden dilakukan dengan menggunakan teknik purposive sampling. Teknik purposive sampling merupakan suatu teknik pengambilan sampel yang didasarkan pada pertimbangan-pertimbangan tertentu yang terkait dan mendukung tujuan penelitian. Pertimbangan-pertimbangan tersebut adalah responden merupakan kelompok tani aktif, memiliki pengalaman bertani minimal 5 tahun, dan pernah/sedang mengikuti Upsus minimal 1 tahun.

Pemberian kuesioner menghasilkan data pengetahuan, sikap, dan tindakan petani pelaku Upsus dalam mengendalikan hama dan penyakit, melakukan kegiatan budi daya padi sawah, dan implementasi tahapan Upsus di tingkat petani. Setelah data diperoleh, data kemudian direkap, dihitung presentasi, dan rataannya lalu disajikan dalam bentuk tabel dan grafik pada Microsoft Office 2013.

\section{HASIL DAN PEMBAHASAN}

\section{Karakteristik Petani Upsus}

Karakteristik responden yang diamati berupa umur, tingkat pendidikan, luas lahan sawah, status kepemilikan lahan, lama bertani, dan kendala yang paling sering dihadapi oleh responden. Karakteristik responden, seperti umur, tingkat pendidikan, dan lama bertani sebenarnya tidak memiliki korelasi yang signifikan dengan tindakan responden dalam menggunakan pestisida. Faktor-faktor yang memengaruhi tindakan responden dalam menggunakan pestisida adalah faktor kebiasaan, kemudahan penggunaan, serta tingkat efektivitas pestisida (Hidayat et al. 2010). Penggunaan pestisida yang dilakukan oleh responden bertujuan untuk mengendalikan hama dan penyakit pada tanaman padi sawah. Faktor-faktor yang memengaruhi keberhasilan pengendalian hama dan penyakit secara kimia adalah faktor kesesuaian pestisida dengan sasaran, kepekaan sasaran, waktu aplikasi, takaran aplikasi, dan cara aplikasi (Djojosumarto 2008).

Umur petani berpengaruh pada penerapan teknologi yang dilakukan oleh petani. Pada saat petani berada pada kisaran umur produktif, petani umumnya akan lebih cepat menyerap informasi yang diperoleh. Kisaran umur produktif petani adalah 18-58 tahun. Jika petani tersebut telah berumur lebih dari 58 tahun maka usia tersebut masuk ke dalam kategori tidak produktif lagi (Hadipurwanta 2015). Umur produktif berpengaruh pada pengambilan keputusan petani. Petani yang memiliki usia produktif memiliki kemampuan bekerja 
dan berpikir yang lebih tinggi dibandingkan dengan petani yang memiliki umur tidak produktif (Ismaili et al. 2015). Sebagian besar responden $(63,33 \%$ di Kecamatan Tempuran dan 56,67\% di Kecamatan Tirtajaya) memiliki umur pada kisaran 41-58 tahun dan termasuk ke dalam kriteria umur produktif (Tabel 1).

Tingkat pendidikan sebagian besar responden di Kecamatan Tempuran dan Tirtajaya adalah Sekolah Dasar (Tabel 1). Tingkat pendidikan berpengaruh pada penyerapan informasi yang diperoleh. Semakin tinggi tingkat pendidikan petani maka akan semakin mudah petani tersebut menyerap materi/informasi penyuluhan, inovasi, dan teknologi yang diberikan.

Luas lahan sawah yang wajib untuk mengikuti Upsus adalah sebesar 2 ha/petani atau 25 ha/ kelompok tani (Dirjen Tanaman Pangan 2015). Luas lahan sebagian besar responden peserta Upsus adalah sebesar $<2$ ha. Keluasan lahan responden sudah sesuai dengan anjuran Upsus. Responden yang memiliki luas lahan $>2$ ha umumnya memberikan sebagian lahan kepada petani lain untuk digarap dengan melakukan perjanjian sistem kontrak atau bagi hasil panen sehingga keseluruhan lahan yang dimiliki masuk ke dalam program pelaksanaan Upsus.

Status kepemilikan lahan terdiri atas pemilik penggarap dan penggarap. Pemilik penggarap adalah responden yang menggarap sendiri lahan yang dimilikinya. Status penggarap dimiliki oleh responden yang menggarap lahan sawah milik orang lain dengan suatu persyaratan tertentu (sistem kontrak, bagi hasil, atau buruh tani). Pengambilan keputusan dalam menerapkan teknologi dan melaksanakan kegiatan budi daya dipengaruhi oleh status kepemilikan lahan responden. Pemilik penggarap akan lebih aktif dalam mengadopsi teknologi/inovasi serta dapat langsung menerapkan pada lahan sawahnya. Pengambilan keputusan yang dilakukan penggarap harus disetujui dulu oleh pemilik lahan dan penggarap sehingga penerapan inovasi dan pengambilan keputusan yang dilakukan penggarap berlangsung agak lambat. Terdapat $63,33 \%$ responden di Kecamatan Tempuran yang merupakan penggarap dan terdapat 53,33\% responden di Kecamatan Tirtajaya yang merupakan pemilik penggarap (Tabel 1). Desakan ekonomi yang dihadapi petani berpengaruh langsung pada status kepemilikan Iahan petani.

Sebagian besar responden di Kecamatan Tempuran dan Tirtajaya memiliki pengalaman bertani selama 10-20 tahun serta telah tergabung dalam kelompok tani selama $>6$ tahun (Tabel 1). Dalam pemberian informasi mengenai pertanian, PPL, POPT dan sales pestisida akan berhubungan langsung dengan kelompok tani. Informasi yang diperoleh petani akan menambah wawasan petani sehingga dapat

Tabel 1 Karakteristik responden di Kecamatan Tempuran dan Tirtajaya

\begin{tabular}{|c|c|c|c|c|}
\hline \multirow{2}{*}{ Peubah } & \multicolumn{2}{|c|}{ Kecamatan Tempuran } & \multicolumn{2}{|c|}{ Kecematan Tirtajaya } \\
\hline & Jumlah petani & $\%$ & Jumlah petani & $\%$ \\
\hline \multicolumn{5}{|l|}{ Umur responden } \\
\hline 21-40 tahun & 4 & 13,33 & 9 & 30,00 \\
\hline 41-58 tahun & 19 & 63,33 & 17 & 56,67 \\
\hline$>58$ tahun & 7 & 23,33 & 4 & 13,33 \\
\hline \multicolumn{5}{|l|}{ Tingkat pendidikan } \\
\hline SD & 14 & 46,67 & 12 & 40,00 \\
\hline SLTP & 8 & 26,67 & 9 & 30,00 \\
\hline SLTA & 5 & 16,67 & 2 & 6,67 \\
\hline PT & 1 & 3,33 & 1 & 3,33 \\
\hline Tidak sekolah & 2 & 6,67 & 6 & 20,00 \\
\hline \multicolumn{5}{|l|}{ Luas lahan } \\
\hline Kurang dari 2 ha & 15 & 50,00 & 20 & 66,67 \\
\hline $2-4$ ha & 8 & 26,67 & 9 & 30,00 \\
\hline Lebih dari 4 ha & 7 & 23,33 & 1 & 3,33 \\
\hline \multicolumn{5}{|l|}{ Status kepemilikan } \\
\hline Pemilik penggarap & 11 & 36,67 & 16 & 53,33 \\
\hline Penggarap & 19 & 63,33 & 14 & 46,67 \\
\hline \multicolumn{5}{|l|}{ Lama bertani } \\
\hline Kurang dari 10 tahun & 3 & 10,00 & 3 & 10,00 \\
\hline 10-20 tahun & 12 & 40,00 & 13 & 43,33 \\
\hline 21-30 tahun & 7 & 23,33 & 11 & 36,67 \\
\hline Lebih dari 30 tahun & 8 & 26,67 & 3 & 10,00 \\
\hline \multicolumn{5}{|l|}{ Tergabung dalam kelompok } \\
\hline Kurang dari 3 tahun & 4 & 13,33 & 2 & 6,67 \\
\hline $3-4$ tahun & 9 & 30,00 & $\overline{7}$ & 23,33 \\
\hline $5-6$ tahun & 4 & 13,33 & 9 & 30,00 \\
\hline Lebih dari 6 tahun & 13 & 43,33 & 12 & 40,00 \\
\hline \multicolumn{5}{|l|}{ Kendala yang sering dihadapi } \\
\hline Hama penyakit & 23 & 76,67 & 22 & 73,33 \\
\hline Modal & 6 & 20,00 & 8 & 26,67 \\
\hline Perubahan cuaca & 1 & 3,33 & 0 & 0,00 \\
\hline
\end{tabular}


melakukan kegiatan budi daya dan mengendalikan hama dan penyakit sesuai anjuran, karena itu lamanya bergabung dalam kelompok tani berpengaruh terhadap pengetahuan, sikap dan Tindakan petani.

Peran aktif PPL dalam melakukan penyuluhan berpengaruh pada keberhasilan pelaksanaan program Upsus di tingkat petani. Pemberian informasi oleh PPL harus dilakukan secara menyeluruh dan tidak terbatas pada pengurus kelompok tani saja. Minimnya informasi yang diperoleh responden mengakibatkan sikap dan tindakan responden dalam mengendalikan hama dan penyakit masih mengacu pada pola dan kebiasaan yang dilakukan sebelumnya.

Hama dan penyakit merupakan kendala terbesar yang dihadapi responden dalam melakukan kegiatan budi daya padi sawah. Terdapat sebesar $76,67 \%$ responden di Kecamatan Tempuran dan 73,33\% responden di Kecamatan Tirtajaya yang menyatakan bahwa kendala terbesar dalam melaksanakan kegiatan budi daya padi sawah adalah serangan hama dan penyakit (Tabel 1). Upaya pengendalian hama dan penyakit yang sering dilakukan adalah penggunaan pestisida kimia. Pestisida kimia mulai dilakukan secara terjadwal oleh responden pada saat tanaman padi mencapai umur 7-10 HST.

\section{Budi Daya Tanaman Padi dengan Penerapan Program Upsus}

Menurut Peraturan Menteri Pertanian nomor 3 tahun 2015, tahapan pelaksanaan program Upsus terdiri atas penyusunan Rencana Defenitif Kebutuhan Kelompok (RDKK), pencairan dana bantuan (dana diperuntukkan bagi pembelian sarana produksi, bantuan biaya tanam, dan bantuan biaya pertemuan kelompok tani sebanyak 4 kali), pembelian paket sarana produksi (varietas unggul, pupuk bersubsidi, dan pestisida), penggunaan varietas unggul, penanaman tepat waktu, pemupukan berimbang, pemberian air secara efektif dan efisien, perlindungan tanaman, serta penanganan panen dan pascapanen. Varietas yang diwajibkan pada program Upsus adalah varietas unggul yang dilepaskan oleh Kementerian Pertanian, bersertifikat, daya tumbuh minimal $80 \%$, kadar air maksimal 13\%, dan kotoran benih maksimal $2 \%$.

Pemupukan yang baik harus dilakukan sebanyak 3 $\mathrm{kali} / \mathrm{musim}$ tanam, yaitu pada saat tanaman berumur 0-14 HST, 21-28 HST, dan 35-50 HST (IRRI 2016). Rekomendasi pemupukan $\mathrm{N}$ harus mengacu pada produktivitas, sedangkan rekomendasi pemupukan $\mathrm{P}$ dan $\mathrm{K}$ mengacu pada unsur hara tanaman. Takaran dan dosis pupuk $\mathrm{N}, \mathrm{P}$, dan $\mathrm{K}$ harus disesuaikan dengan kandungan hara dan tingkat produktivitas tanaman. Penggunaan pupuk majemuk harus tetap menambahkan pupuk tunggal untuk mencukupi nutrisi yang diperlukan tanaman (Permentan Nomor 40 Tahun 2007).

Varietas yang digunakan oleh responden sebelum pelaksanaan Upsus adalah varietas Ciherang (Tabel 2). Hanya sebagian kecil responden yang menggunakan varietas jenis lainnya, seperti varietas Mekongga dan Ketan. Pada saat Upsus dilaksanakan, terdapat $90 \%$ responden di Kecamatan Tempuran yang tetap menggunakan varietas Ciherang dan terdapat $86,67 \%$ responden di Kecamatan Tirtajaya yang mengganti penggunaan varietas Ciherang dengan Inpari 32 (Tabel 2). Penggunaan varietas oleh responden sudah sesuai dengan pedoman teknis program Upsus. Faktor-faktor yang berpengaruh pada pemilihan jenis varietas yang digunakan oleh responden adalah kesiapan hasil panen sebelumnya, kemudahan memperoleh varietas, dan harga jual hasil

Tabel 2 Pengetahuan, sikap, dan tindakan reponden terhadap budi daya padi sawah

\begin{tabular}{|c|c|c|c|c|}
\hline \multirow{2}{*}{ Peubah } & \multicolumn{2}{|c|}{ Kecamatan Tempuran } & \multicolumn{2}{|c|}{ Kecamatan Tirtajaya } \\
\hline & Jumlah petani & $\%$ & Jumlah petani & $\%$ \\
\hline \multicolumn{5}{|l|}{ Varietas sebelum Upsus } \\
\hline Ciherang & 20 & 66,67 & 22 & 73,33 \\
\hline Inpari 32 & 3 & 10,00 & 1 & 3,33 \\
\hline Lainnya & 7 & 23,33 & 7 & 23,33 \\
\hline \multicolumn{5}{|l|}{ Varietas saat Upsus } \\
\hline Ciherang & 27 & 90,00 & 4 & 13,33 \\
\hline Inpari 32 & 3 & 10,00 & 26 & 86,67 \\
\hline \multicolumn{5}{|l|}{ Pola tanam } \\
\hline Jajar legowo & 23 & 76,67 & 27 & 90,00 \\
\hline Baris tanpa legowo & 7 & 23,33 & 3 & 10,00 \\
\hline \multicolumn{5}{|c|}{ Pupuk kimia yang digunakan } \\
\hline Urea, TSP, NPK & 10 & 33,33 & 17 & 56,67 \\
\hline Urea dan NPK & 5 & 16,67 & 0 & 0,00 \\
\hline Urea dan TSP & 15 & 50,00 & 13 & 43,33 \\
\hline \multicolumn{5}{|l|}{ Dosis pupuk kimia per ha } \\
\hline$<5$ ton & 12 & 40,00 & 4 & 13,33 \\
\hline $5-6$ ton & 11 & 36,67 & 19 & 63,33 \\
\hline$>6$ ton & 7 & 23,33 & 7 & 23,33 \\
\hline \multicolumn{5}{|l|}{ Intensitas pemupukan kimia } \\
\hline $1 \mathrm{kali} /$ musim tanam & 2 & 6,67 & 1 & 3,33 \\
\hline 2 kali/musim tanam & 26 & 86,67 & 28 & 93,33 \\
\hline 3 kali/musim tanam & 2 & 6,67 & 1 & 3,33 \\
\hline
\end{tabular}


panen. Faktor ketahanan hama dan penyakit sama sekali tidak diperhatikan.

Program Upsus mewajibkan anggota untuk menerapkan penanaman serempak dengan pola tanam jajar legowo $2: 1$ dan $4: 1$. Jajar legowo $2: 1$ memiliki jarak tanam $(20-40 \mathrm{~cm}) \times 10 \mathrm{~cm},(25-50 \mathrm{~cm}) \times 12,5 \mathrm{~cm}$, dan $(30-60 \mathrm{~cm}) \times 15 \mathrm{~cm}$ sementara jajar legowo $4: 1$ memiliki jarak tanam $(20-40 \mathrm{~cm}) \times 10 \mathrm{~cm}$ dan $(25-50$ $\mathrm{cm}) \times 12,5 \mathrm{~cm}$ (Dirjen Tanaman Pangan 2015). Jarak tanam yang lebar membuat tanaman memiliki ruang untuk menyebar dan memperdalam akar. Akar yang panjang/menyebar berfungsi sebagai alat untuk menjangkau air dan hara yang terdapat di dalam tanah untuk menyokong pertumbuhan tanaman (Hidayati 2015). Sebagian besar responden sudah menerapkan pola tanam jajar legowo dengan jarak tanam yang sesuai dengan anjuran Upsus (Tabel 2). Bantuan biaya tanam sudah dipergunakan sesuai dengan peruntukan.

Jenis pupuk yang digunakan oleh responden berpengaruh pada hasil panen yang diperoleh. Terdapat $50 \%$ responden di Kecamatan Tempuran yang hanya menggunakan pupuk tunggal saja, yaitu Urea dan TSP, sedangkan di Kecamatan Tirtajaya, terdapat $56,67 \%$ responden yang sudah menggunakan pupuk tunggal dan pupuk majemuk, yaitu Urea, TSP, dan NPK (Tabel 2). Intensitas pemupukan yang dilakukan sebagian besar responden adalah 2 kali/ musim tanam. Responden di Kecamatan Tempuran menganggap bahwa tidak perlu dilakukan penambahan NPK karena pada pupuk tunggal sudah terdapat unsur N, P, dan K. Masih terdapat keragaman pemahaman pada pola pikir responden dalam mengimplementasikan konsep pemupukan berimbang. Sebagian petani mengartikan bahwa pemupukan berimbang identik dengan penggunaan pupuk majemuk. Pada lokasi tertentu, penggunaan pupuk majemuk dapat sesuai dengan pemupukan berimbang, tetapi bisa saja di lokasi lain penggunaan pupuk majemuk justru menyebabkan pemborosan karena formulasi hara yang terkandung dalam pupuk majemuk tersebut tidak sesuai dengan yang dibutuhkan oleh tanaman. Oleh karena itu, dalam melakukan aplikasi pemupukan, sangat perlu dilihat unsur hara dan penyesuaiannya dengan anjuran dosis pemupukan.

Total jumlah pupuk yang digunakan sebagian besar responden di Kecamatan Tempuran adalah sebesar $>5$ ton/ha per musim tanam, sedangkan di Kecamatan Tirtajaya adalah sebesar 5-6 ton/ha per musim tanam (Tabel 2). Takaran yang tepat untuk pupuk $\mathrm{N}$ adalah sebanyak 200-400 kg/ha atau mengacu pada besaran produktivitas sebelumnya. Takaran yang tepat untuk pupuk $\mathrm{N}$ dan $\mathrm{K}$ adalah sebesar $50-100 \mathrm{~kg} / \mathrm{ha}$ atau mengacu pada kandungan unsur hara tanaman (Permentan No 40 Tahun 2007). Pemupukan dengan konsep berimbang belum sepenuhnya dilakukan dan diterapkan oleh petani.

\section{Pengetahuan dan Teknik Aplikasi Pestisida oleh Petani}

Upaya pengendalian dominan yang dilakukan oleh petani adalah penggunaan pestisida kimia. Penggunaan pestisida kimia yang tidak sesuai anjuran menimbulkan resistensi dan resurjensi hama serta masalah lingkungan lainnya. Kemampuan petani dalam membedakan hama dan penyakit sangat memengaruhi penggunaan pestisida sesuai dengan sasaran. Kemampuan membedakan hama dan penyakit berpengaruh pada sikap dan tindakan responden dalam mengendalikan hama dan penyakit.

Terdapat 36,67\% responden di Kecamatan Tempuran yang memiliki kemampuan yang baik dalam membedakan antara hama dan penyakit dan terdapat $50 \%$ responden di Kecamatan Tirtajaya yang memiliki kemampuan yang kurang baik dalam membedakan antara hama dan penyakit (Gambar 1). Faktor yang memengaruhi tingkat kemampuan responden dalam membedakan antara hama dan penyakit adalah tingkat perolehan informasi mengenai hama dan penyakit. Peran aktif PPL berpengaruh pada tingkat kemampuan petani dalam membedakan antara hama dan penyakit.

Gagal panen pada musim tanam sebelumnya mengakibatkan tingkat kewaspadaan responden yang tinggi dan memengaruhi peningkatan intensitas penggunaan pestisida kimia. Sebagian besar responden akan langsung mengaplikasikan pestisida kimia jika pada pertanaman terdapat hama atau gejala penyakit walaupun dalam skala yang kecil (Gambar 1). Keberadaan musuh alami dan tingkat ambang batas ekonomi hama sama sekali tidak diperhatikan oleh petani. Kebanyakan petani tidak mengetahui sama sekali mengenai ambang ekonomi hama atau konsep pengendalian hama terpadu.

Pengendalian hama dan penyakit pada program Upsus harus mengacu pada prinsip dan strategi PHT di mana pestisida kimia digunakan sebagai alternatif terakhir jika serangan hama dan penyakit sudah melebihi batas ambang ekonomi. Penggunaan pestisida kimia harus sesuai dengan ketentuan dan peraturan yang berlaku sehingga tidak menimbulkan resistensi, resurjensi, peningkatan hama sekunder, dan dampak lainnya yang merugikan lingkungan (Dirjen Tanaman Pangan 2015). Upaya pengendalian hama dan penyakit yang dilakukan oleh responden sama sekali tidak sesuai dengan anjuran Upsus.

Terdapat 83,33\% responden di Kecamatan Tempuran dan 73,33\% responden di Kecamatan Tirtajaya yang melakukan aplikasi pestisida kimia secara terjadwal dengan tujuan untuk tindakan pencegahan (Tabel 3). Aplikasi pestisida secara terjadwal dimulai pada saat tanaman padi berumur 10 HST dengan selang waktu aplikasi per 7-10 hari. Jika pestisida kimia yang biasa digunakan dianggap tidak mampu lagi mengendalikan hama dan penyakit maka sebagian besar responden di Kecamatan Tempuran 


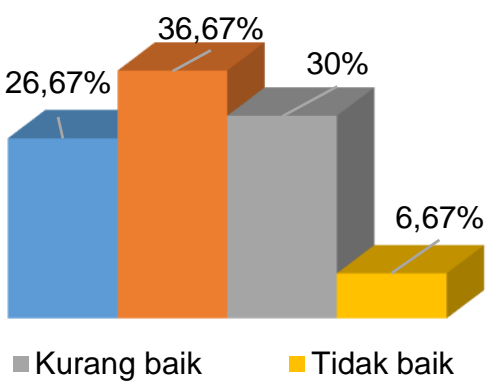

(2a)

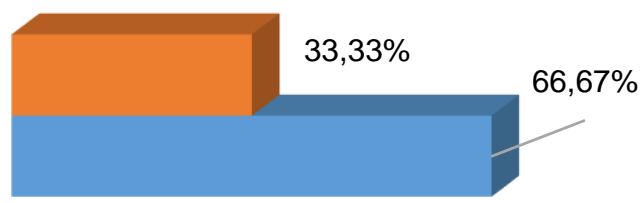

- Langsung dikendalikan (1a)

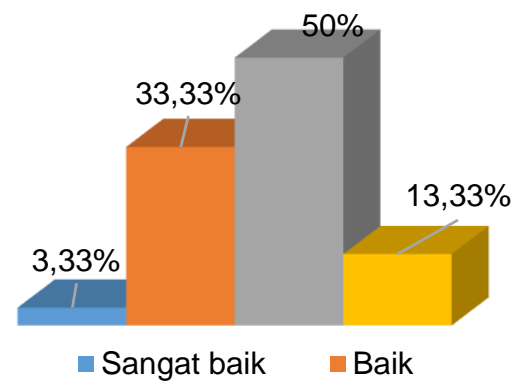

(1b)

Gambar 1 1a) Kemampuan petani dalam membedakan antara hama dan penyakit di Kecamatan Tempuran; 1b) Tirtajaya; 2a) Sikap petani terhadap hama dan penyakit di Kecamatan Tempuran, dan 2b) Tirtajaya.

Tabel 3 Pengetahuan, sikap, dan tindakan responden terhadap pestisida

\begin{tabular}{|c|c|c|c|c|}
\hline \multirow{2}{*}{ Peubah } & \multicolumn{2}{|c|}{ Kecamatan Tempuran } & \multicolumn{2}{|c|}{ Kecamatan Tirtajaya } \\
\hline & Jumlah petani & $\%$ & Jumlah petani & $\%$ \\
\hline \multicolumn{5}{|l|}{ Dasar penggunaan pestisida } \\
\hline Terjadwal & 25 & 83,33 & 22 & 73,33 \\
\hline Bila timbul gejala & 5 & 16,67 & 8 & 26,67 \\
\hline \multicolumn{5}{|l|}{ Aplikasi pestisida } \\
\hline Jenis dan konsentrasi sama & 2 & 6,67 & 5 & 16,67 \\
\hline Jenis sama konsentrasi beda & 17 & 56,67 & 12 & 40,00 \\
\hline Pestisida baru & 11 & 36,67 & 13 & 43,33 \\
\hline \multicolumn{5}{|l|}{ Perbedaan fungsi/jenis pestisida } \\
\hline Tahu & 4 & 13,33 & 4 & 13,33 \\
\hline Kurang tahu & 11 & 36,67 & 16 & 53,33 \\
\hline Tidak tahu & 15 & 50,00 & 10 & 33,33 \\
\hline \multicolumn{5}{|l|}{ Aplikasi pestisida pra-Upsus } \\
\hline$<5 \mathrm{kali} / \mathrm{musim}$ tanam & 0 & 0,00 & 5 & 16,67 \\
\hline 5-10 kali/musim tanam & 26 & 86,67 & 21 & 70,00 \\
\hline$>10 \mathrm{kali} / \mathrm{musim}$ tanam & 4 & 13,33 & 4 & 13,33 \\
\hline \multicolumn{5}{|l|}{ Aplikasi pestisida pada saat Upsus } \\
\hline$<5 \mathrm{kali} /$ musim tanam & 0 & 0,00 & 0 & 0,00 \\
\hline 5-10 kali $/$ musim tanam & 8 & 26,67 & 12 & 40,00 \\
\hline$>10 \mathrm{kali} /$ musim tanam & 22 & 73,33 & 18 & 60,00 \\
\hline \multicolumn{5}{|l|}{ Pestisida kimia kendalikan HPT } \\
\hline $\mathrm{Ya}$ & 25 & 83,33 & 25 & 83,33 \\
\hline Ragu-ragu & 5 & 16,67 & 5 & 16,67 \\
\hline Tidak & 0 & 0,00 & 0 & 0,00 \\
\hline \multicolumn{5}{|l|}{ Aplikasi pestisida anjuran PPL } \\
\hline $\mathrm{Ya}$ & 16 & 53,33 & 8 & 26,67 \\
\hline Tidak & 14 & 46,67 & 22 & 73,33 \\
\hline
\end{tabular}

akan menaikkan dosis/konsentrasi pestisida yang digunakan dan sebagian besar responden di Kecamatan Tirtajaya akan mengganti pestisida lama tersebut dengan pestisida baru (Tabel 3). Responden beranggapan bahwa semakin mahal harga pestisida maka akan semakin ampuh dalam mengendalikan hama dan penyakit. Konsep pengendalian hama dan penyakit yang dilakukan oleh responden tidak sesuai dengan anjuran Upsus.
Pestisida merupakan suatu substansi bahan kimia dan material lain berupa mikroorganisme, virus, dan lainnya yang tujuan penggunaannya untuk mengontrol/ membunuh hama dan penyakit yang menyerang tanaman, bagian tanaman, dan produk pertanian, membasmi rumput/gulma, mengatur, dan menstimulasi pertumbuhan tanaman atau bagian tanaman, namun bukan penyubur. Pestisida terdiri atas herbisida untuk mengendalikan gulma, insektisida untuk 
mengendalikan serangga/hama, fungisida untuk mengendalikan cendawan, nematisida untuk mengendalikan nematoda, bakterisida untuk mengendalikan bakteri, dan rodentisida atau racun vertebrata (Pasaribu 2014). Tiap jenis pestisida memiliki fungsi dan sasaran tersendiri.

Terdapat 50\% responden di Kecamatan Tempuran yang tidak mengetahui perbedaan jenis dan fungsi pestisida dan terdapat 53,33\% responden di Kecamatan Tirtajaya yang kurang tahu mengenai perbedaan jenis dan fungsi pestisida. Tingkat pengetahuan responden yang rendah memengaruhi teknis aplikasi pestisida yang dilakukan. Teknik aplikasi pestisida yang dilakukan oleh responden umumnya tidak sesuai dengan sasaran.

Intensitas penggunaan pestisida sebelum dilaksanakan program Upsus adalah sebanyak 5-10 kali/ musim tanam dan pada saat Upsus dilaksanakan, intensitas aplikasi pestisida meningkat, yaitu sebesar > $10 \mathrm{kali} /$ musim tanam (Tabel 3). Menurut responden, hama dan penyakit pada saat ini dirasa makin kompleks dan kebal terhadap pestisida sehingga intensitas aplikasi pestisida ditingkatkan. Kekebalan hama terhadap pestisida sebenarnya merupakan akibat dari penggunaan pestisida yang tidak sesuai dengan anjuran.

Sebagian besar responden di Kecamatan Tempuran dan Tirtajaya percaya bahwa pestisida kimia mampu mengendalikan hama dan penyakit (Tabel 3). Responden lebih memilih pestisida kimia dibandingkan dengan pestisida organik karena pestisida kimia dianggap lebih cepat dan efisien dalam mengendalikan hama dan penyakit, mudah diperoleh, dan teknik aplikasinya tidak memakan waktu yang lama. Sebagian kecil responden masih memiliki keraguan terhadap pestisida kimia. Keraguan tersebut berasal dari kemampuan responden yang rendah dalam membedakan antara hama dan penyakit sehingga beranggapan bahwa penyakit kurang mampu dikendalikan oleh pestisida kimia. Pestisida hanya mampu mengendalikan hama dan penyakit sasaran apabila pestisida tersebut cocok dengan sasaran. Hama dan penyakit sasaran akan peka terhadap pestisida yang diaplikasikan dengan teknik yang benar. Kegagalan pengendalian hama dan penyakit bisa saja disebabkan oleh ketidaksesuaian antara penggunaan pestisida dengan hama dan penyakit yang disasar (Djojosumarto 2008).

Penggunaan dan teknik aplikasi pestisida yang dilakukan petani seharusnya merupakan anjuran dari PPL/POPT. Sebagian besar responden di Kecamatan Tempuran menyatakan bahwa pestisida yang digunakan sesuai dengan anjuran PPL/POPT, sedangkan di Kecamatan Tirtajaya menyatakan bahwa aplikasi pestisida bukan merupakan anjuran PPL/POPT. PPL/ POPT seharusnya bertanggung jawab penuh dalam menyampaikan informasi dan melakukan pendampingan petani secara terjadwal. Peran serta PPL/POPT diharapkan mampu meningkatkan pengetahuan responden serta mengubah sikap dan tindakan responden dalam mengendalikan hama dan penyakit.

\section{Implementasi Upsus di Tingkat Petani}

Pelaksanaan Upsus di tingkat petani seharusnya mengacu pada pedoman teknis yang dianjurkan oleh Upsus. PPL wajib melakukan pendampingan secara terjadwal dalam pelaksanaan tahapan Upsus di tingkat petani. Peran aktif PPL berpengaruh pada keberhasilan program Upsus di tingkat petani dan berimbas pada peningkatan kepuasan petani pelaku Upsus. PPL wajib memberikan informasi kepada petani mengenai program Upsus dan pedoman teknis yang dianjurkan. Sebagian besar responden mengenal program Upsus melalui ketua gapoktan/ketua kelompok tani (Tabel 4). Pendampingan PPL diduga kurang optimal dan tidak menyeluruh. Informasi yang disampaikan oleh PPL hanya sebatas pada pengurus kelompok tani saja.

Peningkatan produksi padi pada program Upsus diperoleh dari perluasan tambah tanam. Pada setiap musim tanam, instansi terkait akan memberikan target luas tanam petani dan wajib dipenuhi oleh para petani. Sebagian besar responden menyatakan bahwa Upsus mampu meningkatkan produksi padi sawah (Tabel 4).

Rencana Defenitif Kebutuhan Kelompok (RDKK) adalah rencana kebutuhan sarana produksi pertanian dan alat/mesin pertanian untuk satu musim/siklus yang disusun berdasarkan musyawarah anggota kelompok tani. RDKK merupakan salah satu persyaratan untuk memperoleh sarana produksi pertanian kelompok tani dari Gapoktan atau lembaga lain (penyalur sarana produksi pertanian dan perbankan), termasuk perencanaan kebutuhan pupuk bersubsidi (Direktorat Pupuk dan Pestisida 2014). RDKK yang disusun oleh kelompok tani menjadi acuan bagi Dinas Pertanian untuk menetapkan besaran kebutuhan pupuk bersubsidi per musim tanam. Sebagian besar responden di Kecamatan Tempuran dan Tirtajaya tidak mengetahui tentang RDKK. Hal ini membuktikan bahwa penyusunan RDKK yang dilakukan hanya melibatkan pengurus kelompok tani dan PPL saja, tidak melibatkan semua anggota kelompok tani.

Terdapat 50\% responden di Kecamatan Tempuran dan 73,33\% responden di Kecamatan Tirtajaya yang menyatakan bahwa pelaksanaan tahapan Upsus di tingkat petani tidak didampingi oleh PPL (Tabel 4). Tingkat pendampingan petani oleh PPL yang minim berpengaruh pada pengetahuan responden atas pedoman teknis Upsus dan tahapan pelaksanaan Upsus di tingkat petani.

Penanaman secara serempak sudah dilakukan oleh sebagian besar responden (Tabel 4). Sebagian kecil responden tidak melakukan penanaman secara serempak karena kendala banjir. Responden harus menunggu banjir surut dulu baru melakukan persemaian/penanaman. Perbaikan saluran irigasi dan tata guna air perlu dilakukan untuk mengatasi kendala banjir. Program Upsus berhasil meningkatkan pengetahuan para petani. Terdapat $63,33 \%$ responden di Kecamatan Tempuran dan 66,67\% responden di 
Tabel 4 Pengetahuan, sikap, dan tindakan petani terhadap program Upsus

\begin{tabular}{|c|c|c|c|c|}
\hline \multirow{2}{*}{ Peubah } & \multicolumn{2}{|c|}{ Kecematan Tempuran } & \multicolumn{2}{|c|}{ Kecamatan Tirtajaya } \\
\hline & Jumlah petani & $\%$ & Jumlah petani & $\%$ \\
\hline \multicolumn{5}{|l|}{ Yang memperkenalkan Upsus } \\
\hline Ketua gapoktan/kelompok & 18 & 60,00 & 22 & 73,33 \\
\hline PPL/Dinas Pertanian & 12 & 40,00 & 8 & 26,67 \\
\hline \multicolumn{5}{|l|}{ Upsus meningkatkan produksi } \\
\hline $\mathrm{Ya}$ & 16 & 53,33 & 21 & 70,00 \\
\hline Tidak & 14 & 46,67 & 9 & 30,00 \\
\hline \multicolumn{5}{|l|}{ Pengetahuan tentang RDKK } \\
\hline Tahu & 14 & 46,67 & 8 & 26,67 \\
\hline Tidak tahu & 16 & 53,33 & 22 & 73,33 \\
\hline \multicolumn{5}{|l|}{ Upsus didampingi PPL } \\
\hline $\mathrm{Ya}$ & 15 & 50,00 & 8 & 26,67 \\
\hline Tidak & 15 & 50,00 & 22 & 73,33 \\
\hline \multicolumn{5}{|l|}{ Penanaman serempak } \\
\hline $\mathrm{Ya}$ & 27 & 90,00 & 15 & 50,00 \\
\hline Tidak & 3 & 10,00 & 15 & 50,00 \\
\hline \multicolumn{5}{|l|}{ Hasil panen sebelum Upsus } \\
\hline$<7$ ton/ha/MT & 20 & 66,67 & 24 & 80,00 \\
\hline 7-8 ton/ha/MT & 10 & 33,33 & 6 & 20,00 \\
\hline$>8$ ton/ha/MT & 0 & 0,00 & 0 & 0,00 \\
\hline \multicolumn{5}{|l|}{ Hasil panen pada saat Upsus } \\
\hline$<7$ ton/ha/MT & 7 & 23,33 & 9 & 30,00 \\
\hline 7-8 ton/ha/MT & 18 & 60,00 & 20 & 66,67 \\
\hline$>8$ ton/ha/MT & 5 & 16,67 & 1 & 3,33 \\
\hline \multicolumn{5}{|l|}{ Peningkatan pengetahuan } \\
\hline Bertambah & 19 & 63,33 & 20 & 66,67 \\
\hline Tidak & 11 & 36,67 & 10 & 33,33 \\
\hline \multicolumn{5}{|l|}{ Kepuasan terhadap Upsus } \\
\hline Sangat puas & 3 & 10,00 & 1 & 3,33 \\
\hline Puas & 15 & 50,00 & 15 & 50,00 \\
\hline Kurang puas & 11 & 36,67 & 13 & 43,33 \\
\hline Tidak puas & 1 & 3,33 & 1 & 3,33 \\
\hline
\end{tabular}

Kecamatan Tirtajaya yang menyatakan bahwa program Upsus mampu meningkatkan pengetahuan responden (Tabel 4).

Keberhasilan program Upsus akan memengaruhi peningkatan kepuasan petani pelaku Upsus terhadap program Upsus. Di Kecamatan Tempuran, terdapat $50 \%$ responden yang puas, $36,67 \%$ responden yang kurang puas, 3,33\% responden yang tidak puas, dan $10 \%$ responden yang sangat puas dengan program Upsus. Di Kecamatan Tirtajaya, terdapat 50\% responden yang puas, 43,33\% responden yang kurang puas, 3,33\% responden yang tidak puas, dan 3,33\% responden yang sangat puas terhadap program Upsus (Tabel 4). Tingkat kepuasan dipengaruhi oleh hasil panen dan kenaikan produksi yang diperoleh. Responden yang tidak puas/kurang puas adalah responden yang pernah mengalami gagal panen pada musim sebelumnya karena serangan hama dan penyakit.

Dalam pelaksanaannya, terdapat beberapa hal penting yang perlu ditambahkan pada program Upsus. Menurut para responden hal-hal tersebut adalah perbaikan saluran irigasi untuk mengatasi banjir, proses pendampingan PPL secara terjadwal, pelatihan mengenai metode pengendalian hama dan penyakit, bantuan pestisida, dan pemberian informasi oleh PPL secara menyeluruh. Pada saat ini, hal-hal tersebut diduga kurang dilakukan pada pelaksanaan Upsus.
Pemantauan pelaksanaan program Upsus di tingkat petani perlu dilakukan oleh dinas terkait mengingat pendampingan petani yang kurang optimal oleh tenaga PPL dalam pelaksanaan Upsus. Peran aktif PPL perlu ditingkatkan agar dapat mendukung pencapaian keberhasilan pelaksanaan program Upsus.

\section{KESIMPULAN}

Upsus belum mampu mengubah sikap dan tindakan petani dalam mengendalikan hama dan penyakit. Sikap dan tindakan petani dalam menggunakan pestisida dipengaruhi oleh faktor kebiasaan, kemudahan dalam pengunaan, dan tingkat efektivitas pestisida. Karakteristik petani tidak memiliki kolerasi yang signifikan dengan sikap dan tindakan petani dalam mengendalikan hama dan penyakit. Pengendalian hama dan penyakit yang dilakukan petani tidak mengikuti pedoman teknis Upsus. Implementasi pelaksanaan Upsus di tingkat petani belum sepenuhnya mengacu pada pedoman teknis Upsus, namun mengacu pada pola kebiasaan lama yang sering dilakukan sebelumnya. Implementasi tahapan pelaksanaan Upsus di tingkat petani umumnya terlaksana dengan baik, kecuali pada tahapan penyusunan RDKK dan pengendalian hama dan penyakit. 


\section{DAFTAR PUSTAKA}

Dirjen Tanaman Pangan. 2015. Pedoman Teknis GPPTT Padi. Jakarta (ID) : Kementan.

Direktorat Pupuk dan Pestisida. 2014. Petunjuk Pelaksanaan Penyusunan RDKK pupuk bersubsidi. Jakarta (ID): Kementan.

Djojosumarto P. 2008. Teknik Aplikasi Pestisida Pertanian. Jakarta (ID): Kanisius.

Hadipurwanta. 2016. Kajian Pengetahuan dan Sikap Petani terhadap Penggunaan Bahan Organik pada Usaha Tani Padi Sawah di Desa Negararatu, Kecamatan Natar, Kabupaten Lampung Selatan. Dalam: Prosiding Seminar Nasional Agroinovasi Spesifik Lokasi Untuk Ketahanan Pangan Pada Era Masyarakat Ekonomi ASEAN 19-25 Oktober 2016. Bandar Lampung (ID).

Hidayat F, Khamidi T, Wiyono S. 2010. Pengetahuan, Sikap dan Tindakan Petani di Kabupaten Tegal dalam Penggunaan Pestisida dan Kaitannya dengan Tingkat Keracunan Pestisida. Jurnal Bumi Lestari. 10(1): 1-12.

Hidayati N. 2015. Fisiologi, Anatomi, dan Sistem Perakaran pada Budidaya Padi dengan Metode System of Rice Intensification dan Pengaruhnya terhadap Produksi. [Tesis]. Bogor (ID): Institut Pertanian Bogor.

[IRRI] International Rice Research Institute. 2016. Pemupukan Padi Sawah berdasarkan Target Hasil Panen. [internet]. [diunduh pada Januari 2016]. Tersedia pada http://www. knowledgebank.irri.org
Ismilali I, Purnaningsing N, Asngari PS. 2015. Tingkat Adopsi Inovasi Pengelolaan Tanaman Terpadu Padi Sawah di Kecamatan Leuwiliang, Kabupaten Bogor. Jurnal Penyuluhan. 11(1). 49-59 https://doi.org/ 10.25015/penyuluhan.v11i1.9931

Kementrian Pertanian. 2007. Peraturan Menteri Pertanian Republik Indonesia Nomor 40 Tahun 2007 tentang Rekomendasi Pemupukan N, P dan K pada Sawah Spesifik lokasi. Jakarta (ID): Kementan

Kementrian Pertanian. 2015. Peraturan Menteri Pertanian Republik Indonesia Nomor 3 Tahun 2015 tentang Pedoman Upaya Khusus (upsus), Peningkatan Produksi Padi, Jagung dan Kedelai melalui Program Perbaikan Irigasi dan Sarana Pendukungnya. Jakarta (ID): Kementan

Kementrian Pertanian. 2017. Produksi, Luas Panen dan Produktivitas Padi di Indonesia 2013-2017. [internet]. [diunduh pada 2017 April 02]. Tersedia pada http://www.pertanian.go.id/ap_pages/mod/ datatp

Muhamad A. 1996. Perilaku Petani SLPHT dan Non SLPHT dalam Pelaksanaan PHT pada Tanaman Kubis di Kabupaten Karo, Propinsi Sumatera Utara [Skripsi]. Bogor (ID): Institut Pertanian Bogor.

Pasaribu Y. 2014. Analisis residu Pestisida Golongan Piretroid pada Beberapa Sayuran di Kota Merauke. Agricola. 4(1): 41-48.

Untung K. 2006. Pengantar Pengelolaan Hama Terpadu. Yogyakarta (ID): Gadjah Mada University Press. 